\title{
Ewidencja i digitalizacja spuścizny po artyście rzeźbiarzu Franciszku Duszeńce w Bibliotece Akademii Sztuk Pięknych w Gdańsku
}

STRESZCZENIE: Biblioteka Akademii Sztuk Pięknych w Gdańsku w 2015 r. realizowała projekt z programu „Ochrona i cyfryzacja dziedzictwa kulturowego”, dofinansowany ze środków Ministerstwa Kultury i Dziedzictwa Narodowego. Zadanie to związane było z profilem uczelni, a także z zapoczątkowaną w $1982 \mathrm{r}$. przez rektora prof. Franciszka Duszeńkę inicjatywą gromadzenia obiektów muzealnych związanych z działalnością artystów współtworzących dziedzictwo artystyczne Akademii Sztuk Pięknych w Gdańsku. Bibliotekarze kontynuowali za pomocą współczesnych środków to, co chciał zawrzeć Duszeńko w momencie zainicjowania galerii. Celem artykułu jest zwrócenie uwagi na różne dokumenty i obiekty muzealne, które były ważnymi elementami spuścizny. Należało je w pierwszej kolejności uporządkować, poddać ewidencji i opracować, a następnie zdigitalizować i udostępnić. Praca nad opracowaniem spuścizny wymagała od bibliotekarzy znajomości życia i twórczości Duszeńki, szczególnie na etapie uporządkowania zbioru. Zadanie było podzielone na etapy, po ukończeniu pierwszego z nich Biblioteka ASP w Gdańsku upowszechniła pierwszą część spuścizny składającą się z 720 zdigitalizowanych zdjęć przedstawiających prace profesora oraz z 1500 rysunków stanowiących zamknięty, nigdy wcześniej nie udostępniony zbiór prac. 
SŁowA KLuczowE: Biblioteka Akademii Sztuk Pięknych w Gdańsku, digitalizacja, Duszeńko Franciszek, kolekcje muzealne, prawo autorskie.

G romadzenie polskiego dziedzictwa narodowego, jego przechowywanie dla następnych pokoleń i jak najszersze udostępnienie jest powinnością instytucji, których zadaniem jest dbałość o zasoby kultury. Od końca XX wieku wprowadzają one nowoczesne metody zabezpieczania dóbr kultury, tworząc ich cyfrowe odwzorowania, udostępniane milionom użytkowników z całego świata - dzięki nowym technologiom komunikacyjnym - za pomocą Internetu" ${ }^{1}$. Przytoczona przez autorkę idea związana z digitalizacją i upowszechnieniem zbiorów przyświecała Bibliotece Akademii Sztuk Pięknych [dalej: ASP] w Gdańsku w 70. rocznicę powstania uczelni. W 2015 r. Biblioteka² złożyła wniosek do Ministerstwa Kultury i Dziedzictwa Narodowego [dalej: MKiDN] o dofinansowanie realizacji projektu: „Digitalizacja i ewidencja spuścizny po artyście rzeźbiarzu Franciszku Duszeńce”. Miał być to drugi, tym razem samodzielny, projekt polegający na digitalizacji zbiorów i ich udostępnieniu, realizowany przez uczelnianą Bibliotekę. Pierwszym było wspólne przedsięwzięcie bibliotek trójmiejskich - Pomorska Biblioteka Cyfrowa, omawiane przez Annę Polańską na I Ogólnopolskiej Konferencji Naukowej „Ochrona Zbiorów Bibliotecznych. Przyszłość - Teraźniejszość Przeszłość", która odbyła się w Bydgoszczy w dniach 19-20 maja 2016 r. Inicjatywa ta uzyskała dofinansowanie w ramach Regionalnego Programu Operacyjnego dla Województwa Pomorskiego na lata 2007-2013.

Instytucją zarządzającą programem, w ramach którego realizowano drugi projekt, był Narodowy Instytut Muzealnictwa i Ochrony Zabytków [dalej: NIMiOZ]. Całkowity koszt zadania wyniósł 32 006,50 zł, w tym dotacja MKiDN to $24000 \mathrm{zł}$, a wkład własny ASP 8006,50 zł. Trwało ono od 4 maja do 31 grudnia 2015 r. Jego przedmiotem było zdigitalizowanie

${ }^{1}$ Raport o digitalizacji dóbr kultury [online]. Warszawa: Ministerstwo Kultury i Dziedzictwa Narodowego, 2009, 67 s. [dostęp 31 marca 2017]. Dostępny w World Wide Web: http://nck.pl/media/attachments/302378/program_digitalizacji_20092020_copy3.pdf, s. 4.

${ }^{2}$ W okresie realizowania projektu pracownikami Biblioteki Akademii Sztuk Pięknych [dalej: ASP] w Gdańsku były: Małgorzata Dąbrowska, Anna Polańska, Anna Zelmańska-Lipnicka. 
i opracowanie spuścizny po profesorze Franciszku Duszeńce otrzymanej w 2013 r. jako dar od żony artysty, Urszuli Ruhnke-Duszeńko, na podstawie umowy darowizny ${ }^{3}$. U. Ruhnke-Duszeńko przekazała uczelni zespół, na który składały się rysunki, fotografie - zarówno osobiste, jak i te dokumentujące pracę artystyczną męża - a także inne dokumenty o ważnym znaczeniu dla rozwoju kultury i sztuki, w tym dokumentacje projektowania i budowy pomników, prywatna i zawodowa korespondencja, liczne recenzje pisane przez profesora oraz przemówienia okolicznościowe. Ze względu na wartość merytoryczną i historyczną spuścizny, na słaby stan jej zachowania (papier, który stanowił główną część daru był słabej jakości i uległ zakwaszeniu), a także na osobę, której dotyczyła, zdecydowano o jej zdigitalizowaniu.

Franciszek Duszeńko urodził się 6 kwietnia 1925 r. w Gródku Jagiellońskim koło Lwowa, zmarł 11 kwietnia 2008 r. w Gdańsku. Był artystą rzeźbiarzem i pedagogiem. Przez jego pracownię przewinęli się artyści rzeźbiarze, którzy swoim nieprzeciętnym stosunkiem do twórczości wpisali się w historię rzeźby i sztuki polskiej. Duszeńko w latach 1942-1944 studiował w Państwowym Instytucie Sztuk Plastycznych we Lwowie, w pracowni prof. Mariana Wnuka. Od lipca 1943 do czerwca 1944 r. należał do Armii Krajowej we Lwowie (pseud. „Gustaw”). Następnie - od 3 lipca 1944 do 8 maja 1945 r. - był więźniem obozów koncentracyjnych: Gross Rosen, Oranienburg i Sachsenhausen (nr obozowy: 86262). Po wyzwoleniu przebywał w Warszawie, Zakopanem i Łodzi. Próbował odnaleźć swojego lwowskiego profesora - Mariana Wnuka. Do 1947 r. kontynuował naukę w Państwowej Szkole Przemysłu Artystycznego w Łodzi, a następnie studia w pracowni prof. Mariana Wnuka w Państwowej Wyższej Szkole Sztuk Pięknych w Gdańsku z siedzibą w Sopocie [dalej: PWSSP], funkcjonującej obecnie jako ASP w Gdańsku. Dyplom uzyskał w 1952 r., ale już dwa lata wcześniej rozpoczął pracę pedagogiczną w gdańskiej PWSSP jako asystent. W 1956 r. uzyskał stopień docenta oraz został kierownikiem i prowadzącym Pracownię Rzeźby I roku. W latach 1960-1964 pełnił funkcję dziekana uczelni. W 1964 r. objął kierownictwo Katedry i Pracowni Dyplomującej Rzeźby. W 1973 r. mianowano go profesorem

${ }^{3}$ Umowa o przeniesienie autorskich praw majątkowych została zawarta między Urszula Ruhnke-Duszeńko a Akademią Sztuk Pięknych 13 grudnia 2013 r. Umowa zdeponowana w Bibliotece ASP w Gdańsku. 
nadzwyczajnym PWSSP w Gdańsku. W 1981 r. wygrał pierwsze demokratyczne wybory na stanowisko rektora macierzystej uczelni i pełnił tę funkcję przez dwie kadencje, w latach 1981-1987. Od 1987 do 1996 r. (w międzyczasie, w 1990 r., otrzymał tytuł profesora zwyczajnego) kierował Katedrą Rzeźby i Rysunku. Do 2001 r. sprawował opiekę pedagogiczną nad dyplomantami. Od roku 1970, kiedy to dyplomanci byli przypisywani do profesora, do roku 2001 z jego pracowni wyszło ponad 80 dyplomantów. Był autorem licznych recenzji na stopnie docenta i profesora. Należał do Związku Polskich Artystów Plastyków. F. Duszeńko był rzeźbiarzem pracującym głównie nad nowoczesną formą pomnika. Stanowiła ona dla niego wyzwanie, które próbował realizować, łącząc rzeźbę z przestrzenią, dla jakiej projektował pomnik. Realizacje poprzedzał licznymi szkicami. Założenie pomnikowe miało współgrać z przestrzenią poprzez formę i ideę. Do realizacji pomników zapraszał architektów, m.in. Adama Haupta. Oprócz prac pomnikowych F. Duszeńko stworzył szereg nadzwyczaj udanych podobizn rzeźbiarskich o pogłębionym psychologicznym wyrazie oraz aktów czy torsów, w których reminiscencje antyku przenikają się ze świeżością i nowoczesnością spojrzenia. Prace Profesora znajdują się w zbiorach Muzeum Narodowego w Warszawie i w Gdańsku, a także w Muzeum Medalierstwa we Wrocławiu i w New Delhi. Profesor Duszeńko odbył liczne zawodowe podróże zagraniczne, m.in. do Związku Radzieckiego, Włoch, Indii, Niemieckiej Republiki Demokratycznej, na Kubę oraz - prywatnie - do Grecji i Egiptu4. Franciszek Duszeńko był mężem wspomnianej wyżej Urszuli Ruhnke-Duszeńko (1922-2014), malarki, studentki w pracowni prof. Juliusza Studnickiego, gdzie w 1954 r. uzyskała dyplom. W latach 1952-1971 pracowała w PWSSP, początkowo w Pracowni Malarstwa prof. Juliusza Studnickiego, a następnie prowadziła Pracownię Malarstwa na Wydziale Architektury Wnętrz ASP w Gdańsku. Syn Profesora, Marcin Duszeńko (1958-2000), był malarzem, grafikiem i rysownikiem. Studiował w gdańskiej PWSSP w latach 1977-1983. Dyplom uzyskał w pracowni prof. Jerzego Zabłockiego w 1983 r. Był adiunktem w pracowni prof. Włodzimierza Łajminga.

${ }^{4}$ Duszeńko Franciszek. W: E-kultura, [online]. Akademia Sztuk Pięknych w Gdańsku [dostęp 31 marca 2017]. Dostępny w World Wide Web: http://ekultura.asp.gda.pl/pl/e-kultura-profesorowie. 
Do grona studentów Franciszka Duszeńki należał nieżyjący prof. Zbigniew Pidek, a także obecni profesorowie ASP i pedagodzy: prof. Ludmiła Ostrogórska, prof. Janina Rudnicka (Janina Kowalska), prof. Grzegorz Klaman, dr hab. Robert Kaja, dr hab. Magdalena Góra (Magdalena Schmidt), dr hab. Marek Targoński, a także rzeźbiarze niezwiązani z pracą pedagogiczną w ASP: Bogdan Markowski, Henryk Lademann, Jerzy Kędziora, Tomasz Misztal, Janusz Tkaczuk, Eugeniusz Szczudło, Waldemar Cichoń, Anna Baumgart, Julita Wójcik, Małgorzata Brygida Dunaj.

Darowany przez U. Ruhnke-Duszeńko zbiór był nieuporządkowany i nieopisany. W skład kolekcji wchodziły zasoby o charakterze bibliotecznym, w postaci zbiorów specjalnych, a także zasób rysunków o charakterze muzealnym. Jednocześnie był to zbiór o charakterze jednostkowym i niepowtarzalnym; stanowił całość dającą świadectwo o człowieku, którego dotyczył. Ważnym działaniem było wydzielenie zbioru przeznaczonego do opracowania i digitalizacji, ponieważ budżet przeznaczony na realizację projektu, z powodu mniejszego od planowanego dofinansowania ministerialnego, został ograniczony. Podczas realizacji zadania bibliotece pomocą merytoryczną służył dr hab. R. Kaja, który był studentem Profesora. Bibliotekarze musieli przede wszystkim podjąć się rozpoznania zawartości zbioru, stanu jego uporządkowania, zebrania przydatnych w porządkowaniu i ewidencji zasobu informacji, a także opracowania układu zbioru z podziałem na podzbiory. Zostały przeprowadzone klasyfikacja, systematyzacja, inwentaryzacja (ewidencja) i opis fotografii w zespole. Klasyfikacja polegała na podziale fotografii w ramach zasobu na działy, grupy czy podgrupy lub tematy na podstawie fotografii i jej opisu (jedna lub kilka fotografii połączonych ze sobą elementem chronologicznym, tj. wykonanych w tym samym lub zbliżonym czasie, przedstawiających określone wydarzenie, zjawisko, osobę lub przedmiot). Systematyzacja służyła nadaniu zasobowi ostatecznego układu. Została przeprowadzona w ramach danego podtematu pod względem chronologicznym lub logicznym.

Inwentaryzacja (ewidencja) rozumiana była jako formowanie jednostki inwentarzowej, składającej się z pojedynczej fotografii, kilku fotografii, albumu. W trakcie inwentaryzacji została nadana sygnatura archiwalna, np. A/I/1. Część fotografii wymagała dodatkowego opisania w zespole. Uwagi zostały naniesione w dodatkowej rubryce „Uwagi”. Dla każdej fotografii sporządzono osobny opis inwentarzowy. Ewidencji, 
ochronie poprzez skanowanie, opracowaniu metadanych i udostępnieniu w Internecie zostało poddanych:

- 520 fotografii dokumentujących prace rzeźbiarskie Profesora z pierwszych lat studiów, a także dokumentujących główne założenia pomnikowe,

- 1500 rysunków.

Zostały założone dwa inwentarze: I/A - na potrzeby zbioru fotografii i I/B - dla rysunków. Uporządkowanie pierwszego zasobu nie stanowiło dużego problemu. W pracy wzorowano się na wydanej w 2014 r. monografii Profesora Franciszek Duszeńko 1925-2008, pod redakcją R. Kai, M. Schmidt-Góry i Anny Zelmańskiej-Lipnickiej ${ }^{5}$, gdzie zamieszczone fotografie zostały opisane, a także określono datę powstania dzieła rzeźbiarskiego i zbliżoną datę powstania fotografii go dokumentującej. Można je było powiązać z innymi tematycznie zgrupowanymi przedstawieniami rzeźb i pomników Profesora i połączyć je chronologicznie. Klasyfikacja polegała na podziale fotografii $\mathrm{w}$ ramach zbioru na grupy oraz podgrupy i uzależniona była od liczby fotografii w zespole (zbiorze) i ich treści. Aby nadać zespołowi ostateczny układ, została przeprowadzona chronologiczna i logiczna systematyzacja fotografii w obrębie tematów. W trakcie klasyfikacji i systematyzacji nie dokonano brakowania zbioru przeznaczonego do digitalizacji w ramach projektu, tym bardziej że w trakcie tych prac brakowanie fotografii powinno być przeprowadzone z dużą ostrożnością. Mogą mu podlegać fotografie, które z uwagi na przedstawiony temat nie posiadają wartości dokumentalnej. Dodatkowo wykaz przeznaczonych do wybrakowania fotografii $\mathrm{w}$ formie zapisu wymaga przedstawienia do zatwierdzenia właściwej komisji ds. oceny archiwalnej fotografii ${ }^{6}$.

${ }^{5}$ Franciszek Duszeńko 1925-2008, pod red. R. Kai, M. Schmidt-Góry, A. Zelmańskiej-Lipnickiej, Gdańsk 2014.

${ }^{6}$ A. Modzelewska, Dokumentacja fotograficzna, Legnica 2006, s. 6; J. Michałowska, Opracowanie dokumentacji aktowej [online]. Warszawa: Ośrodek KARTA, 2012, 20 s. [dostęp 31 marca 2017]. Dostępny w World Wide Web: http://archiwa. org/as/as_img/uploaded/12.Archiwa_spoleczne_podrecznik_Michalowska.pdf; Katalog Dobrych Praktyk Digitalizacji materiałów archiwalnych [online]. Narodowy Instytut Muzealnictwa i Ochrony Zbiorów [dostęp 31 marca 2017]. Dostępny w World Wide Web: http://nimoz.pl/upload/Programy_ministra/OCDK/Katalogi _zalecenia_2015/Katalog_praktyk_i_standardow_digitalizacji_materialow_archiwalnych. pdf. 
Fotografie zostały podzielone na osiem grup:

I/A/1 Prace z okresu nauki w Państwowej Szkole Przemysłu Artystycznego w Łodzi i PWSSP w Sopocie,

I/A/2 Pomnik Ofiar Obozu Zagłady w Treblince,

I/A/3 Pomnik Obrońców Westerplatte w Gdańsku,

I/A/4 Pomnik Marii Konopnickiej w Gdańsku,

I/A/5 Płaskorzeźba Kopernik na zamku w Malborku,

I/A/6 Pomnik Polskich Artylerzystów w Toruniu,

I/A/7 Figura Chrystusa do kościoła św. Józefa w Gdyni-Leszczynkach,

I/A/8 Rewitalizacja miejsca pamięci narodowej Westerplatte.

Z wykorzystaniem fotografii wiązała się kwestia prawa autorskiego, zostały one bowiem wykonane w okresie od lat 40. do lat 80. XX w. Brano pod uwagę ustawy o prawie autorskim z 1926 r. (art. 3), z 1952 r. (art. 2 par. 1) i z 4 lutego 1994 r. (art. 124, par. 1, pkt 3). Pomocne były w tym wypadku decyzje sądu w sprawach karnych przytoczone w dokumencie Prawne aspekty digitalizacji i udostępnienia zbiorów muzealnych przez Internet (Warszawa 2014), zredagowanym przez Ewę Kamińską i wydanym przez NIMOZ7 . Fotografia podlega ochronie prawnoautorskiej, kiedy stanowi przejaw działalności twórczej o indywidualnym stylu. Musi mieć charakter kreacyjny, oryginalny, wywołany niepowtarzalną osobowością twórcy. Za twórczość w dziedzinie fotografii artystycznej przyjęto zdjęcia wykonane w odpowiednim momencie, z odpowiedniego punktu widzenia, cechujące się indywidualną kompozycją, oświetleniem, ustaleniem indywidualnych parametrów zdjęcia, te wszystkie elementy wprowadzają do fotografii indywidualne piętno, konieczne do uznania utworu w rozumieniu prawa autorskiego ${ }^{8}$.

W orzecznictwie Sądu Najwyższego wskazano, że w dziedzinie fotografii należy odróżnić przedmiot fotografii, który sam może być dziełem, i to innego autorstwa, od wykonania nośnika tego dzieła, jakim jest jego fotografia. Fotografia może być jedynie wybranym przez twórcę

${ }^{7}$ Prawne aspekty digitalizacji i udostępniania zbiorów muzealnych przez Internet, red. E. Kamińska [online]. Warszawa: Narodowy Instytut Muzealnictwa i Ochrony Zbiorów, 2014 [dostęp 31 marca 2017]. Dostępny w World Wide Web: http://digitalizacja. nimoz.pl/uploads/zalaczniki/Prawne_aspekty_digitalizacji_i_udostepniania_NIMOZ_ 2014.pdf.

8 Cechy fotografii uznane w wyroku Sądu Najwyższego z dnia 5 lipca 2002 r., III CKN 1096/2000, OCNC 2003/11, poz. 150. 
dzieła sposobem utrwalenia przedmiotu fotografii, który ma charakter nietrwały .

Jeśli chodzi o tzw. stare fotografie, należy podkreślić, że ustawy o prawie autorskim z 1926 i 1952 r. chroniły fotografię jako utwór, ale pod warunkiem spełnienia przez samego fotografa pewnych wymogów o charakterze formalnym. Chodziło o zastrzeżenie prawa autorskiego, które mogło być dokonane wyłącznie przez twórcę fotografii w rozumieniu przepisów ustawy o prawie autorskim i prawach pokrewnych.

Najlepiej kwestię zastrzeżenia prac autorskich obrazuje przykład sprawy dotyczącej portretu Miry Zimińskiej-Sygietyńskiej autorstwa Jerzego Dorysa ze zbiorów Polony (http://www.polona.pl/ item/5867217/1/). Przepis art. 3 prawa autorskiego z 1926 r. wskazywał, że aby fotografia była chroniona prawem autorskim, należało na odbitkach i reprodukcjach zdjęć uwidocznić rok wykonania zdjęcia lub przeniesienia. Natomiast zgodnie z art. $2 \S 1$ prawa autorskiego z 1952 r. fotografia była objęta prawem autorskim tylko wtedy, kiedy było na niej widoczne zastrzeżenie prawa autorskiego, łącznie z podaniem roku powstania fotografii. Jeżeli więc w czasie obowiązywania poprzednich ustaw autor nie opatrzył wykonanego zdjęcia zastrzeżeniem, zdjęcie takie nie było chronione przez prawo autorskie - ochrona prawnoautorska nie powstawała i można było z fotografii korzystać i ją rozpowszechniać. Do takich fotografii prawo autorskie nie odżywało ${ }^{10}$. Prawo mogło odżyć tylko do tych fotografii, które według Ustawy z 10 lipca 1952 r. o prawie autorskim przysługiwały twórcy, lecz na skutek upływu czasu wygasły. Ustawodawca nie precyzował, w jakiej formie i w jaki sposób należy uczynić zastrzeżenie prawa autorskiego. Mogła być to forma „prawa autorskie zastrzeżone”, „wszelkie prawa zastrzeżone”, ,wszelkie kopiowanie zabronione”, „prawa autorskie posiada..." lub nota copyright wraz z nazwiskiem autora na odwrocie fotografii i rokiem wydania, np. „Copyright ...” czy znak (C). Według ustawy samo podpisanie zdjęcia nie stanowiło zastrzeżenia prawa autorskiego, a jedynie wskazywało autora. Zastrzeżenie było dokonywane na fotografii, jej materialnym nośniku i na odbitkach.

9 Tamże.

${ }^{10}$ Instytucja odżycia praw autorskich wiąże się z uchwaleniem nowej ustawy przedłużającej czas trwania autorskich praw majątkowych. Polega na ponownej ochronie utworów, do których prawo - według starej ustawy - już wygasło. 
Jednak brak sygnatury na fotografii i jej odbitkach nie pozbawiał do końca ochrony prawnoautorskiej dzieła fotograficznego - autor fotografii mógł domagać się ochrony, jeśli wykazał, że osoba prywatna czy instytucja musiała wiedzieć, iż fotografia była chroniona przez prawo autorskie. Jeżeli więc podmiot, np. muzeum, rozpowszechniał w dobrej wierze odbitki nieopatrzone zastrzeżeniem prawa autorskiego, to twórca - fotograf może dochodzić swoich roszczeń, wyłącznie dowodząc, że muzeum wiedziało o zastrzeżeniu prawa autorskiego do fotografii i mając tę wiedzę, naruszyło jego prawa autorskie ${ }^{11}$. Te problemy prawne związane z zastrzeżeniem lub nie praw autorskich fotografii pojawiły się również w kontekście opracowywanego zbioru. Bibliotekarze włożyli wiele starań, aby określić autorstwo zdjęć (na ile to było możliwe) i w efekcie nie naruszyć praw autorskich fotografów.

Drugi zbiór wymagał od bibliotekarzy dużej znajomości twórczości Franciszka Duszeńki, ponieważ nie był on uporządkowany. Rysunki były pomieszane, nieopisane przez autora, niedatowane. Podobnie jak w przypadku fotografii, pomocna okazała się monografia Profesora. W rezultacie rysunki zostały podzielone na 14 podzespołów. Szukano analogii z pracami rzeźbiarskimi, jednak części rysunków nie udało się opisać i przyporządkować do określonych zbiorów. Między innymi dlatego powstały dwa zbiory: I/B/12 - Różne założenia pomnikowe i I/B/14 - Projekty różne niezidentyfikowane.

W rezultacie zostało wydzielonych 14 podzespołów:

I/B/1 Pomnik Ofiar Obozu Zagłady w Treblince,

I/B/2 Pomnik Obrońców Westerplatte i Cmentarz Poległych Obrońców Westerplatte,

I/B/3 Tematyka sakralna,

I/B/4 Pomnik Polskich Artylerzystów w Toruniu,

I/B/5 Struktury,

I/B/6 Medale,

I/B/7 Mikołaj Kopernik,

I/B/8 Maria Skłodowska-Curie,

I/B/9 Włodzimierz Lenin,

I/B/10 Martyrologia,

11 Wyrok Sądu Najwyższego z 6 czerwca 2002 r. Zob. Prawne aspekty digitalizacji i udostępniania zbiorów muzealnych przez Internet..., s. 39. 
I/B/11 Cmentarz Łostowicki w Gdańsku, Kwatera Żołnierzy AK, I/B/12 Różne założenia pomnikowe,

I/B/13 Tematyka muzyczna,

I/B/14 Projekty różne niezidentyfikowane.

Prawa do drugiego zbioru rysunków przekazała w całości Akademii Sztuk Pięknych żona Profesora. Oba zbiory z powodu braku środków finansowych nie zostały poddane konserwacji, a tylko zabezpieczeniu poprzez zapakowanie ich części składowych w koperty zapobiegające zakwaszaniu papieru. Po zakupieniu sprzętu i przeszkoleniu pracowników rozpoczęto skanowanie, stosując się do wymagań zawartych w Katalogu Dobrych Praktyk Digitalizacji materiałów archiwalnych.

Dla każdego zbioru został utworzony folder odpowiadający nazwie i sygnaturze skanowanego zasobu. Dokumentacja pozytywowa czarno-biała została zdigitalizowana w rozdzielczości 600 dpi, w 8-bitowej skali szarości, w formacie zapisu TIFF bez kompresji. Brak kompresji pozwala zachować najwierniejszą kopię w stosunku do oryginału. Dla każdego zdigitalizowanego obiektu utworzono metryczkę z metadanymi technicznymi i opisowymi, zapisaną w formacie JPG. Do większości skanów dołączono wzorzec barwny. Zastosowano zasadę jak najbardziej wiernego odzwierciedlenia zbioru. Niektóre fotografie z powodu dużego formatu zostały zeskanowane bez wzorca barwnego. Innych parametrów skanowania wymagały rysunki, które są kolorowe - różnica polegała na zastosowaniu skali barwnej. W opisie rysunków nie uwzględniono szczegółowej daty ich powstania. Określono ją w sposób przybliżony datami obejmującymi okres twórczości Duszeńki. Udostępnienie zdigitalizowanego zbioru nastąpiło na stronie internetowej Biblioteki w zakładce Nauka/Granty pod adresem http://asp.gda.pl/pl/biblioteka_nauka_ granty. W późniejszym czasie Biblioteka ma zamiar umieścić zdigitalizowaną spuściznę w Pomorskiej Bibliotece Cyfrowej opisaną w formacie Dublin Core.

Za pośrednictwem metadanych udostępnione w Internecie muzealia mogą być zidentyfikowane przez korzystających. Duże znaczenie ma poprawny zapis metadanych, klarowne reguły ich udostępnienia oraz dbałość o to, by opublikowane online reprodukcje muzealiów były właściwie powiązane ze swoimi metadanymi. Zgodnie z Rozporządzeniem Ministra Kultury z 30 sierpnia 2004 r. w sprawie zakresu, form i sposobu ewidencjonowania zabytków w muzeach (Dz.U. 2004, nr 202, poz. 2073) zespół 
bibliotekarzy z ASP w Gdańsku stworzył metadane opisowe muzealiów obejmujące informacje jednoznacznie identyfikujące obiekt.

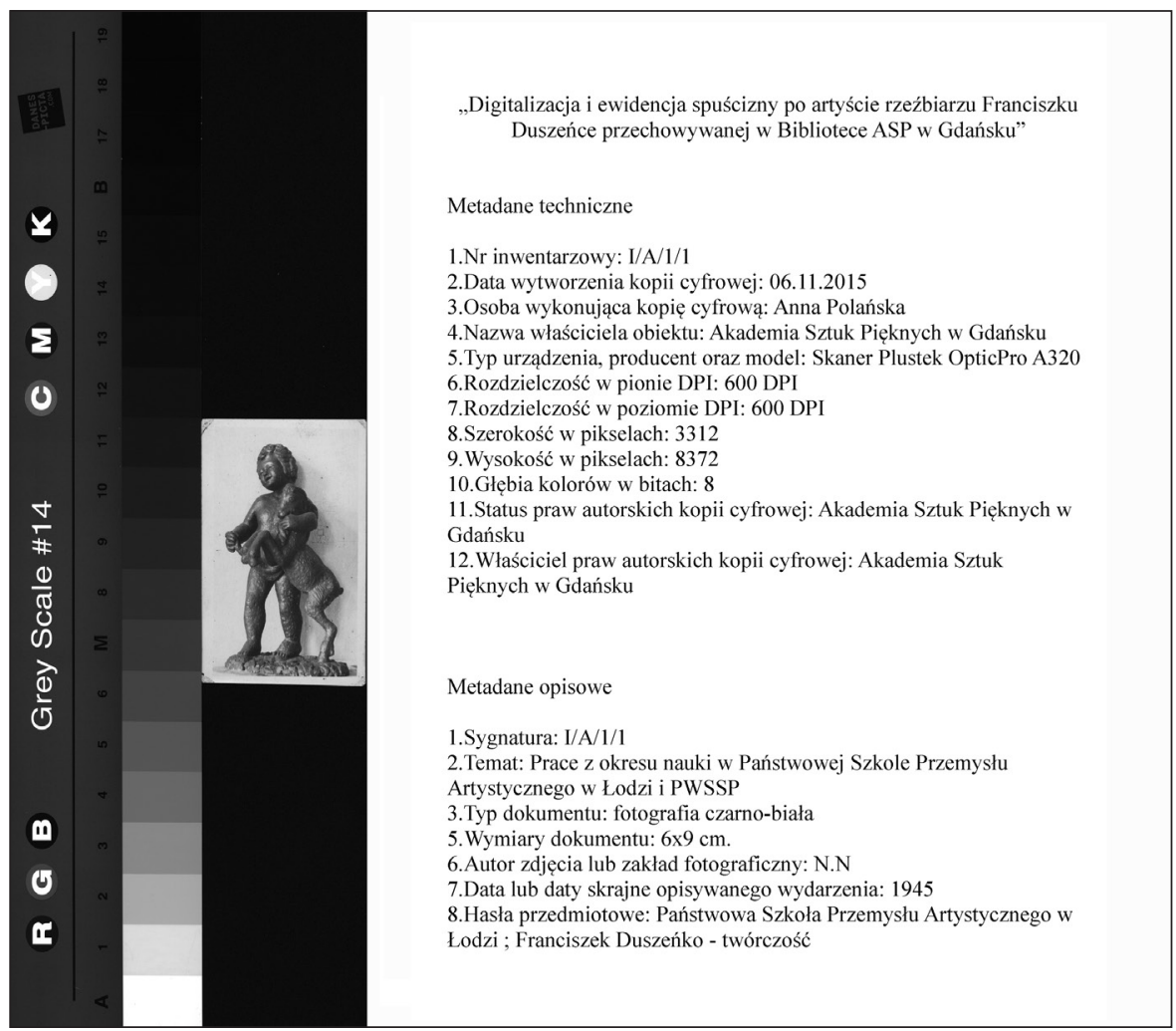

Ilustracja 1. Fotografia zeskanowana z wzorcem szarości i wykonana do niej metryczka z danymi technicznymi i opisowymi

Źródło: opracowanie Anna Polańska.

Wysokiej jakości skany - z metryczkami i kopiami inwentarzy zostały przekazane NIMOZ. Projekt zarówno podczas trwania, jak i po jego zakończeniu był promowany w portalach społecznościowych, prasie i w Radiu Gdańsk - podczas audycji poświęconej Profesorowi i spuściźnie po Nim. Zostały wysłane maile informujące o zdigitalizowanym zbiorze do bibliotek zlokalizowanych przy muzeach, centrach kultury, a także do zakładów historii sztuki przy uniwersytetach. 


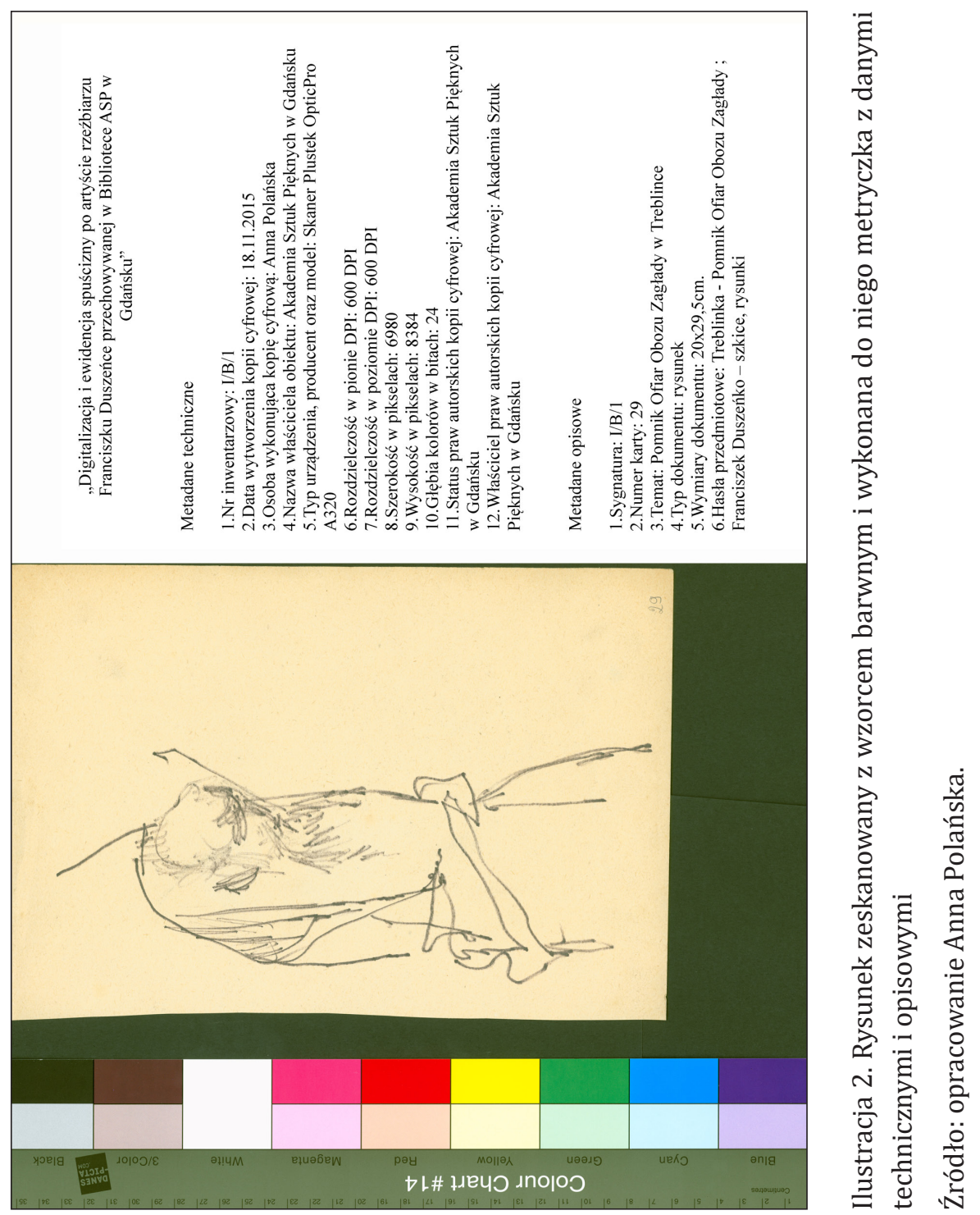


Po zakończeniu realizacji projektu został nakręcony film promujący przedsięwzięcie i przedstawiający sylwetkę prof. Franciszka Duszeńki. W ciągu dwóch miesięcy od zakończenia projektu film miał ponad 200 emisji, jest nadal dostępny na stronie Biblioteki pod adresem: http://asp. gda.pl/pl/biblioteka_nauka_granty.

Realizacja projektu ze środków finansowych Ministerstwa Kultury i Dziedzictwa Narodowego przyczyniła się do ochrony zbioru, a Biblioteka ASP w Gdańsku mogła zaprezentować go szerszemu gronu odbiorców. W normalnych warunkach (tj. bez pomocy ministerialnej, a siłami własnymi), ze względu na zły stan zachowania rysunków i fotografii, nie byłoby to możliwe.

\section{Bibliografia}

Duszeńko Franciszek. W: E-kultura, [online]. Akademia Sztuk Pięknych w Gdańsku [dostęp 31 marca 2017]. Dostępny w World Wide Web: http://ekultura.asp.gda.pl/pl/e-kultura-profesorowie.

Franciszek Duszeńko 1925-2008, pod red. Roberta Kai, Magdaleny Schmidt-Góry, Anny Zelmańskiej-Lipnickiej, Gdańsk 2014.

Katalog Dobrych Praktyk Digitalizacji materiałów archiwalnych [online]. Narodowy Instytut Muzealnictwa i Ochrony Zbiorów [dostęp 31 marca 2017]. Dostępny w World Wide Web: http://nimoz.pl/upload/Programy_ministra/OCDK/Katalogi_zalecenia_2015/Katalog_praktyk_i_standardow_digitalizacji_materialow_archiwalnych.pdf.

Modzelewska Anna, Dokumentacja fotograficzna, Legnica 2006.

Michałowska Janina, Opracowanie dokumentacji aktowej [online]. Warszawa: Ośrodek KARTA, 2012, 20 s. [dostęp 31 marca 2017]. Dostępny w World Wide Web: http://archiwa.org/as/as_img/uploaded/12.Archiwa_spoleczne_podrecznik_Michalowska.pdf.

Prawne aspekty digitalizacji i udostępniania zbiorów muzealnych przez Internet, red. E. Kamińska [online]. Warszawa: Narodowy Instytut Muzealnictwa i Ochrony Zbiorów, 2014 [dostęp 31 marca 2017]. Dostępny w World Wide Web: http://digitalizacja.nimoz.pl/uploads/zalaczniki/Prawne_aspekty_ digitalizacji_i_udostepniania_NIMOZ_2014.pdf.

Raport o digitalizacji dóbr kultury [online]. Warszawa: Ministerstwo Kultury i Dziedzictwa Narodowego, 2009, 67 s. [dostęp 31 marca 2017]. Dostęp- 
ny w World Wide Web: http://nck.pl/media/attachments/302378/program_digitalizacji_20092020_copy3.pdf

Umowa z dnia 13 grudnia 2013 r. o przeniesienie autorskich praw majątkowych zawarta pomiędzy Urszula Ruhnke-Duszeńko a Akademią Sztuk Pięknych w Gdańsku reprezentowaną przez Rektora prof. Ludmiłę Ostrogórską zdeponowana w Bibliotece ASAP w Gdańsku.

\section{The Register and Digitization of the Legacy of the Artist Sculptor Franciszek Duszeńko at the Library of the Academy of Fine Arts in Gdańsk}

ABSTRACT: In 2015, the Library of the Academy of Fine Arts in Gdansk undertook a project "Protection and digitalization of cultural heritage", supported by The Ministry of Culture and National Heritage. The task was associated with the Academy profile as well as an initiative started in 1982 by the Rector prof. Franciszek Duszeńko to collect museum objects relating to the activities of artists co-creating the artistic heritage of the Academy of Fine Arts in Gdansk. Using modern technology, Academy's librarians have been continuing what Duszeńko attempted to achieve while creating the gallery. The aim of the article is to draw attention to the important elements in the development of heritage which consists of various documents and museum objects. First of all, the job was about making order, collecting records, listing them, digitizing and making the files available. The task was divided into stages. After completing the first one, the Library popularized the first part of the legacy consisting of 720 digitized images of Professor Duszeńko's works and 1,500 drawings which have never been publically presented before.

KEYWORDS: Biblioteka Akademii Sztuk Pięknych w Gdańsku, copyright, digitalization, Duszeńko Franciszek, museum collections. 